\title{
KUALITAS TES SUMATIF MATA PELAJARAN MATEMATIKA KELAS VIII SEMESTER GENAP SMP NEGERI 20 KENDARI TAHUN PEMBELAJARAN 2016/2017
}

\author{
Wa Ode Sariasi Supriadi ${ }^{1)}$, Utu Rahim ${ }^{2)}$, Zamsir ${ }^{3)}$ \\ ${ }^{1)}$ Alumni Jurusan Pendidikan Matematika, ${ }^{2,3)}$ Dosen Jurusan Pendidikan Matematika FKIP Universitas \\ Halu Oleo: e-mail: sariasi_supriadi@yahoo.com; uturahim56@gmail.com; zamsir@uho.ac.id
}

\begin{abstract}
Abstrak
Penelitian ini bertujuan: (1) Untuk mengetahui tingkat kesukaran setiap butir soal tes, (2) Untuk mengetahui daya pembeda setiap butir soal tes, (3) Untuk mengetahui validitas setiap butir soal tes, (4) Untuk mengetahui pengecoh (distractor) pada setiap butir soal tes berfungsi atau tidak berfungsi, (5) Untuk mengetahui reliabilitas tes, (6) Untuk mengetahui kesalahan baku pengukuran (KBP) tes. Dari pengolahan data diperoleh kesimpulan: (1) Tingkat kesukaran soal pilihan ganda dan soal essay belum termasuk baik, (2) Daya pembeda soal pilihan ganda dan soal essay belum menpunyai daya pembeda baik, (3) Validitas soal pilihan ganda dan soal essay sudah mempunyai validitas baik, (4) Distractor (pengecoh) sudah berfungsi, (5) Besarnya indeks reliabilitas soal pilihan ganda sebesar 0,541 termasuk memiliki reliabilitas yang sedang. Sedangkan soal essay mempunyai indeks reliabilitas sebesar 0,645 termasuk memiliki reliabilitas sedang, (6) Besarnya kesalahan baku pengukuran (KBP) soal pilihan ganda sebesar 2,255. Sedangkan soal essay mempunyai kesalahan baku pengukuran sebesar 7,686.
\end{abstract}

Kata Kunci: kualitas tes, reabilitas tes, indeks daya beda

\section{THE QUALITY OF THE SUMMATIVE TEST OF MATHEMATICS SUBJECTS CLASS VIII EVEN SEMESTER OF SMP NEGERI 20 KENDARI YEAR OF LEARNING 2016/2017}

\begin{abstract}
The aim of this study: (1) To know the level of difficulty of each item test, (2) To know the differentiating power of each item test, (3) To know the validity of each item test, (4) To know the deception of each item test, (5) To know the reliability of test, (6) To know standard error of measurement test. From the data processing obtained conclusion: (1) The difficulty level of multiple choice question and question description not including either, (2) The differentiating power of multiple choice question and essay question does not have a differentiating power either, (3) The validity of multiple choice question and essay question already have good validity, (4) The deception already function, (5) The magnitude of the multiple choice question reliability index of 0,541 including having moderate reliability, while the essay question has reliability index of 0,645 including having moderate reliability, (6) The magnitude of standard error of measurement of multiple choice question of 2,255, while the essay question has a standard error of measurement of 7,686.
\end{abstract}

Keyword: quality test, reliabilty of tes, discrimination index 


\section{Pendahuluan}

Pendidikan dipandang sebagai faktor utama dalam bidang pembangunan, pandangan ini mengandung suatu pengertian bahwa pendidikan dapat memotori dan menopang proses pembangunan (Aliati dan Ibrahim, 2013: 1). Pendidikan juga memiliki kontribusi besar dalam mempersiapkan manusia yang berkualitas dan mengarahkan siswa untuk memahami perannya sebagai manusia yang bertanggung jawab untuk melanjutkan dan meningkatkan pembangunan. Peningkatan kualitas pendidikan adalah salah satu aspek pembangunan yang memegang peranan penting dalam suatu usaha untuk mencapai pembangunan secara menyeluruh. Salah satu faktor penyebab dalam pelaksanaan sistem pendidikan adalah evaluasi belajar atau pencapaian hasil belajar siswa. Keberadaan evaluasi belajar sangat diperlukan dalam kegiatan belajar mengajar berlangsung karena terdapat proses pembelajaran, penilaian, dan evaluasi. Evaluasi merupakan proses yang sangat penting dalam suatu kegiatan yang dilakukan guru untuk mengetahui keberhasilan peserta didik dalam mencapai pembelajaran yang telah dipelajari sebelumnya. Pelaksanaan evaluasi sangat erat kaitannya dengan guru, dimana dalam proses belajar mengajar salah satu peran guru adalah sebagai evaluator dalam memantau keberhasilan siswa.

Guru sebagai evaluator harus memperhatikan persyaratan-persyaratan evaluasi agar memperoleh hasil yang diharapkan dalam upaya mengukur tingkat penguasaan masingmasing siswa pada materi yang telah diajarkan. Dalam melakukan evaluasi, guru memberikan tes sesuai dengan materi yang telah diajarkan. Oleh karena itu, perlu diciptakan alat ukur untuk mengetahui keberhasilan siswa, alat ukur itulah yang sering disebut dengan tes (tes buatan guru). Tes buatan guru memiliki peran penting dalam proses pembelajaran. Dalam pembuatan soal, guru diharuskan untuk menyusun secara baik supaya mempunyai kualitas tes yang baik, sesuai dengan kurikulum dan sesuai dengan materi yang telah diajarkan. Kualitas tes buatan guru dapat mempengaruhi kualitas pembelajaran dan sekaligus kualitas hasil belajar siswa. Tes sumatif dilakukan setelah di akhir suatu pelajaran atau akhir semester dimaksudkan untuk mengukur apa yang telah dipelajari peserta didik setelah suatu keseluruhan pembelajaran. Hasil tes ini digunakan untuk banyak hal antara lain: untuk pemberian nilai siswa, evaluasi efektifitas kurikulum,menilai pencapaian akademik siswa, sekolah, ataupun daerah secara umum selama tahun akademik berjalan (Liliasari, 2015: 39).

Yusuf (2015: 19) menyatakan bahwa evaluasi merupakan suatu proses pengumpulan dan analisa data secara sistematis untuk mengetahui bukti penguasaan peserta didik dalam belajar, ketercapaian tujuan yang telah ditetapkan dan menentukan keefektifan pendidikan atau pembelajaran. Menurut Arifin (2012: 6-7) tes pada hakikatnya adalah suatu alat yang berisi serangkaian tugas yang harus dikerjakan atau soalsoal yang harus dijawab oleh peserta didik untuk mengukur suatu aspek prilaku tertentu. Artinya, tes tersebut adalah sebagai alat ukur. Tes subjektif yang pada umumnya berbentuk essay (uraian). Tes bentuk essay adalah sejenis tes kemajuan belajar yang memerlukan jawaban yang bersifat pembahasan atau uraian kata-kata (Arikunto, 2016: 177). Tes objektif yang juga dikenal dengan istilah jawaban pendek, adalah salah satu jenis tes hasil belajar yang terdiri dari butir-butir soal (item) yang dijawab oleh testee dengan jalan memilih salah satu diantara beberapa kemungkinan jawaban yang telah dipasangkan pada masing-masing item, atau dengan jalan menuliskan jawabannya berupa kata-kata atau simbol-simbol tertentu pada tempat atau ruang yang telah disediakan untuk masing-masing butir item yang bersangkutan (Sudijono, 2015: 106107).

Persoalan yang penting dalam melakukan analisis tingkat kesukaran adalah tingkat penentuan proporsi dan kriteria soal yang termasuk mudah, sedang dan sukar. Sudijono (2015: 370) menyatakan bahwa butir-butir soal tes hasil belajar dapat dinyatakan sebagai butir-butir tes yang baik, apabila butir-butir soal tersebut tidak terlalu sukar atau tidak terlalu mudah dengan kata lain derajat kesukaran item itu adalah sedang atau cukup. Daryanto (2001: 183) menyatakan bahwa soal-soal yang dianggap baik yaitu soal sedang dengan indeks kesukaran 0,31 sampai dengan 0,70. Butir soal yang memiliki tingkat 
kesukaran tidak baik harus diperbaiki sesuai dengan kategorinya. Bila tingkat kesukaran berkategori mudah, maka harus diperbaiki agar tidak terlalu mudah bagi siswa dan bila tingkat kesukaran berkategori sukar, maka soal diperbaiki agar tidak terlalu sukar bagi siswa.

Tingkat kesukaran (difficulty level) pada analisis butir soal secara klasik merupakan skala rata-rata peserta tes yang menjawab benar suatu butir soal. Menurut Liliasari (2015: 40) hasil perhitungan kriteria indeks kesukaran butir soal mengacu kepada indeks kesukaran yang dilambangkan dengan $\mathrm{P}$ yang diklasifikasikan sebagai berikut:

$0,00-0,30 \quad$ Soal Sukar

$0,31-0,70 \quad$ Soal Sedang

0,71-1,00 Soal Mudah

Sudijono (2015: 385) menyatakan bahwa daya pembeda item adalah kemampuan suatu butir soal tes hasil belajar untuk dapat membedakan (mendiskriminasi) antara siswa yang berkemampuan tinggi (pandai), dengan siswa yang berkemampuan rendah (bodoh) sedemikian sehingga sebagian besar siswa yang memiliki kemampuan tinggi untuk menjawab butir soal tersebut lebih banyak menjawab benar, sementara siswa yang berkemampuan rendah untuk menjawab butir soal tersebut sebagian besar tidak dapat menjawab soal dengan benar. Suatu soal yang dapat dijawab benar oleh siswa yang tinggi (pandai) maupun siswa bodoh, maka soal itu tidak baik karena tidak mempunyai daya pembeda. Demikian pula jika semua siswa yang pandai maupun siswa yang bodoh tidak dapat menjawab dengan benar. Soal yang baik adalah soal yang dijawab benar oleh siswa-siswa yang pandai saja (Arikunto, 2016: 226). Indeks daya pembeda (diskriminasi) soal dilambangkan dengan huruf D (singakatan dari discriminatory power), dan indeks daya pembeda berkisar antara $-1,00$ sampai dengan $+1,00$. Semakin tinggi daya pembeda suatu soal maka semakin baik soal itu.

Apabila angka indeks diskriminasi soal dari sebutir soal bertanda negatif, maka butir soal yang bersangkutan lebih banyak dijawab benar oleh testee yang bodoh ketimbang testee yang pandai, atau testee yang sebenarnya termasuk dalam kategori pandai lebih banyak yang jawabannya salah, sedangkan testee yang sebenarnya dalam kategori bodoh justru lebih banyak yang jawabannya benar. Arikunto (2016: 227) menyatakan bahwa cara menentukan daya pembeda (nilai D) dibedakan atas 2 kelompok yaitu antara kelompok kecil (kurang dari 100 orang) dan kelompok besar (100 orang ke atas). Untuk kelompok kecil: seluruh kelompok tes dibagi dua sama besar, 50\% kelompok atas $\left(\mathrm{J}_{\mathrm{A}}\right)$ dan $50 \%$ kelompok bawah $\left(\mathrm{J}_{\mathrm{B}}\right)$. Seluruh pengikut tes, dideretkan mulai dari skor teratas sampai terbawah, lalu dibagi 2 (dua), sedangkan untuk kelompok besar: mengingat biaya dan waktu untuk menganalisis, maka untuk kelompok besar biasanya hanya diambil $27 \%$ skor teratas sebagai kelompok atas $\left(\mathrm{J}_{\mathrm{A}}\right)$ dan $27 \%$ skor terbawah sebagai kelompok bawah $\left(\mathrm{J}_{\mathrm{B}}\right)$. Daryanto (2001: 190) menyatakan bahwa butir-butir soal yang baik adalah butir-butir soal yang indeks diskriminasi 0,4 - 0,7. Adapun klasifikasi daya pembeda menurut Arikunto (2016: 232) adalah sebagai berikut:

D : $0,00-0,20$ : jelek

D : $0,21-0,40$ : cukup

$\mathrm{D}: 0,41-0,70$ : baik

D : $0,71-1,00$ : baik sekali

D : negatif, semuanya tidak baik (jelek sekali). Jadi semua butir soal yang mempunyai nilai D negatif sebaiknya dibuang saja.

Menurut Aliati dan Ibrahim (2013: 5) salah satu syarat suatu tes dikatakan sebagai alat ukur yang baik adalah memiliki validitas. Suatu tes dikatakan valid apabila tes tersebut dapat mengukur apa yang hendak dan seharusnya diukur. Jadi validitas itu merupakan tingkat ketepatan tes tersebut dalam mengukur materi dan perilaku yang harus diukur. Validitas item dikatakan valid apabila mempunyai dukungan yang besar terhadap skor total. Skor pada item menyebabkan skor total menjadi tinggi atau rendah. Sudijono (2015: 183) menyatakan bahwa validitas dari masing-masing butir item yang membangun tes itu dapat diketahui dengan jalan melihat besar kecilnya dukungan yang diberikan oleh masing-masing butir item yang bersangkutan terhadap tes secara keseluruhan.

Arikunto (2016: 89) menyatakan bahwa koefisien korelasi selalu terdapat anatar -1,00 sampai $+1,00$. Koefisien negatif menunjukkan hubungan kebalikan sedangkan koefisien positif menunjukkan adanya kesejajaran untuk mengadakan interprestasi mengenai besarnya 
koefisien korelasi. Penafsiran harga koefisien korelasi ada 2 (dua) cara, yaitu dengan melihat harga $r$ ( $r$ hitung) dan diiterpretasikan misalnya korelasi tinggi, cukup, dan sebagainya. Dengan berkonsultasi ke ( $\mathrm{r}$ tabel) tabel harga kritik $r$ product moment sehingga dapat diketahui valid tidaknya korelasi tersebut. Jika harga $\mathrm{r}_{\text {hit }}$ ( $\mathrm{r}$ hitung) lebih kecil dari $r_{\text {tab }}$ ( $r$ tabel), maka korelasi tersebut invalid. Begitu juga arti sebaliknya.

Pola jawaban soal yang dimaksud di sini adalah distribusi peserta tes (testee) dalam hal menentukan pilihan jawaban pada soal bentuk pilihan ganda. Pola jawaban soal diperoleh dengan menghitung banyaknya testee. Pola jawaban soal dapat ditentukan apakah pengecoh (distractor) berfungsi sebagai pengecoh dengan baik atau tidak. Pengecoh yang tidak dipilih sama sekali oleh testee berarti pengecoh itu tidak berfungsi dengan baik. Tujuan utama dari pemasangan distractor pada setiap butir item adalah agar dari sekian banyak testee yang mengikuti tes hasil belajar ada yang tertarik atau terangsang untuk memilihnya sebab mereka menyangka bahwa distractor yang mereka pilih itu merupakan jawaban benar. Jadi mereka terkecoh, mereka menganggap bahwa distractor yang terpasang pada item itu sebagai kunci jawaban item padahal bukan. Adapun kriteria indeks klasifikasi penafsiran untuk pengecoh yang ditetapkan penulis berdasarkan pendapat para ahli di atas adalah pengecoh dikatakan berfungsi dengan baik jika paling sedikit dipilih 5\% dari pengikut tes.

Reliabilitas merupakan kriteria ukuran apakah suatu alat ukur dapat mengukur secara konsisten sesuatu yang akan diukur dari waktu ke waktu. Reliabilitas merujuk pada derajat keajegan (consistency) alat tersebut dalam mengukur apa saja yang diukurnya. Tes yang reliabel adalah tes yang konsisten. Jika tes itu diulang, aka skor siswa akan tetap sama dengan hasil yang mereka peroleh pada saat pertama mereka menempuh tes tersebut. Syarat kepercayaan dalam tes adalah ketetapan. Tes yang dapat dipercaya adalah tes yang mempunyai ketetapan hasil. Arikunto (2016: 121) menyatakan bahwa kriteria yang digunakan untuk menafsirkan reliabilitas tes diklasifikasikan sebagai berikut:

$0,00-0,20$ reliabilitas sangat rendah $0,21-0,40$ reliabilitas rendah
$0,41-0,69$ reliabilitas sedang

$0,70-0,89$ reliabilitas tinggi

$0,90-1,00$ reliabilitas sangat tinggi

Sukardi (2015: 50) menyatakan bahwa kesalahan baku pengukuran merupakan estimesi tentang bagaimana seorang peneliti evaluasi mengharapkan kesalahan dari tes yang telah dibuat. Sitti Fatimah (2014: 41-42) menyatakan bahwa kesalahan baku pengukuran pada umumnya dapat juga menunjukkan tingkat reliabilitas tes. Jika nilai kesalahan baku pengukuran suatu tes yang telah dibuat kecil, berarti reliabilitas tes tersebut tinggi. Sebaliknya, jika nilai kesalahan baku pengukuran besar, berarti bahwa tes yang telah dibuat mempunyai reliabilitas mudah. Kesalahan baku pengukuran dalam tes disebabkan oleh kesalahan pengambilan sampel peserta tes (sampling eror), dan kesalahan pelaksanaan tes itu sendiri.

\section{Metode}

Penelitian ini adalah penelitian kuantitatif yang menggunakan jenis penelitian deskriptif. Penelitian ini telah dilaksanakan pada bulan Juni di SMP Negeri 20 Kendari tahun pembelajaran 2016/2017. Subjek penelitian ini adalah lembar jawaban siswa dengan jumlah sebanyak 88 . Teknik pengumpulan data yang digunakan dalam penelitian ini adalah metode dokumentasi. Metode ini digunakan karena data yang diambil berupa dokumen soal, lembar jawaban, dan kunci jawaban ulangan semester peserta tes matematika kelas VIII semester genap di SMP Negeri 20 Kendari tahun pembelajaran 2016/2017. Instrumen yang digunakan dalam penelitian ini adalah tes, khususnya tes matematika yang disusun oleh guru mata pelajaran di kelas VIII SMP Negeri 20 Kendari.

Data yang dikumpulkan dalam penelitian ini akan dianalisis setiap butir soalnya. Data yang akan dianalisis menggunakan 2 teknik analisis data yaitu menggunakan cara manual dan dengan program klasik iteman. Untuk soal pilihan ganda menggunakan program klasik iteman dan untuk soal essay (uraian) menggunakan cara manual. Adapun rumus-rumus dalam penelitian ini adalah sebagai berikut:

Untuk mengetahui tingkat kesukaran butir soal dapat diperoleh dengan menggunakan rumus: 
a) Soal Pilihan Ganda

$$
\boldsymbol{P}=\frac{\boldsymbol{B}}{\boldsymbol{J} \boldsymbol{S}} \quad \text { (Arikunto, 2016: 223) }
$$

Keterangan:

$\mathrm{P}=$ Indek kesukaran

$\mathrm{B}=$ Jumlah siswa yang menjawab soal itu dengan benar

JS = Jumlah seluruh siswa peserta tes

b) Soal Essay

$$
T K=\frac{S_{A}+S_{B}}{n \text { maks }}
$$

(Jihad dan Haris 2012: 182)

Keterangan:

TK = Tingkat kesukaran

$S_{A}=$ Jumlah skor kelompok atas

$S_{B}=$ Jumlah skor kelompok bawah

$\mathrm{n} \quad=$ Jumlah siswa kelompok atas dan

kelompok bawah

maks $=$ Skor maksimal butir soal

Perbandingan proporsi soal yang mudah, sedang, dan sukar misalnya dibuat $3: 4: 3$. Ini berarti $30 \%$ soal kategori mudah, $40 \%$ soal kategori sedang, dan 30\% soal kategori sukar. Perbandingan lain misalnya, $3: 5: 2$. Ini berarti tes tersebut terdiri dari $30 \%$ soal kategori mudah, $50 \%$ soal kategori sedang, dan $20 \%$ termasuk dalam kategori sukar (Erlina A, 2012: 28).

Untuk menentukan daya pembeda butir soal dapat diperoleh dengan menggunakan rumus:

a) Soal pilihan ganda

$$
\boldsymbol{D}=\frac{\boldsymbol{B}_{A}}{\boldsymbol{J}_{A}}-\frac{\boldsymbol{B}_{B}}{\boldsymbol{J}_{B}}
$$

(Arikunto,

2016: 228)

Keterangan:

$\mathrm{J}_{\mathrm{A}}=$ Jumlah peserta kelompok atas

$\mathrm{J}_{\mathrm{B}}=$ Jumlah peserta kelompok bawah

$$
r_{X Y}=\frac{N \sum X Y-\left(\sum X\right)\left(\sum Y\right)}{\sqrt{\left\{N \sum X^{2}-\left(\sum X\right)^{2}\right\}\left\{N \sum Y^{2}-\left(\sum Y\right)^{2}\right\}}}
$$

Keterangan:

Untuk menentukan tingkat reliabilitas tes

$r_{X Y}=$ Koefisien korelasi antara variabel $\mathrm{X}$ dan variabel $\mathrm{Y}$, dua variabel yang dikorelasikan

$\mathrm{N}=$ Jumlah peserta tes

$\mathrm{X}=$ Jumlah skor seluruh siswa pada tiap-

tiap butir soal

$$
\mathrm{Y}=\text { Jumlah skor siswa pada seluruh butir }
$$

$\mathrm{B}_{\mathrm{A}}=$ Jumlah peserta kelompok atas yang menjawab soal itu dengan benar

$\mathrm{B}_{\mathrm{B}}=$ Jumlah peserta kelompok bawah yang menjawab soal itu dengan benar

b) Soal Essay

$$
D P=\frac{S_{A}-S_{B}}{1 / 2 n \cdot m a k s}
$$

(Jihad dan Haris

2012: 189)

Keterangan:

DP = daya pembeda

$S_{A} \quad=$ jumlah skor kelompok atas

$S_{B} \quad=$ jumlah skor kelompok bawah

$\mathrm{n} \quad=$ jumlah siswa kelompok atas

dan kelompok bawah

maks = skor maksimal butir soal

Hendriana \& Soemarmo (2014: 62) menyatakan bahwa untuk menentukan validitas item untuk soal pilihan ganda menggunakan rumus korelasi point biserial dan untuk soal essay menggunakan rumus product moment dengan angka kasar, yaitu sebagai berikut:

a) Soal pilihan ganda

$$
r_{p b i s}=\frac{M_{P}-M_{t}}{S D_{t}} \sqrt{\frac{p}{q}}
$$

Keterangan:

$r_{\text {pbis }}=$ Koefisien korelasi point biserial

$M_{P}=$ Mean skor hitung yang dimiliki peserta tes untuk butir soal yang dicari telah dijawab dengan benar

$M_{t}=$ Mean skor total

$S D_{t}=$ Deviasi Standar dari skor total

$\mathrm{P}=$ Mean dari skor total yang dijawab dengan benar

$$
\mathrm{q}=1-\mathrm{p}
$$

b) Soal Essay soal pilihan ganda menggunakan rumus K-R 20 dan soal tes essay menggunakan rumus Alpha:

a) Soal pilihan ganda

$$
r_{11}=\left(\frac{n}{n-1}\right)\left(\frac{s_{t}{ }^{2}-\sum p q}{S_{t}{ }^{2}}\right)
$$

(Yusuf, 2015: 81)

Keterangan: soal

$r_{t t}=$ reliabilitas tes secara keseluruhan 
$\mathrm{p}=$ Proporsi subjek yang menjawab butir soal dengan benar

$\mathrm{q}=$ Proporsi subjek yang menjawab butir soal dengan salah $(\mathrm{q}=1-\mathrm{p})$

$\sum p q=$ Jumlah hasil perkalian antara $\mathrm{p}$ dan $\mathrm{q}$

$\mathrm{n}=$ Jumlah butir soal

$\mathrm{S}_{\mathrm{t}}=$ Standar deviasi dari skor total

b) Soal Essay

$$
r_{11}=\left(\frac{n}{n-1}\right)\left(1-\frac{\sum S_{i}{ }^{2}}{S_{t}{ }^{2}}\right)
$$

(Sudijono, 2015: 208)

Keterangan:

$r_{11}=$ koefisien reliabilitas tes dalam tes

$\mathrm{n}=$ jumlah butir soal yang dikeluarkan

1 = bilangan konstan

Dalam penelitian ini sutau tes dikatakan memiliki reliabilitas yang baik minimal dalam kategori sedang $(0,41-0,69)$.

Sukardi (2015: 51) menyatakan bahwa untuk mengetahui besarnya kesalahan baku pengukuran (standar error of measurement) tes digunakan rumus:

$$
S m=S D \sqrt{1-r_{11}}
$$

$$
\begin{aligned}
& \text { Keterangan: } \\
& \begin{aligned}
\mathrm{Sm} & =\text { kesalahan baku pengukuran } \\
\mathrm{SD} & =\text { simpangan baku skor tes } \\
r_{11} & =\text { koefisien reliabilitas }
\end{aligned}
\end{aligned}
$$

\section{Hasil}

Tes Sumatif Mata Pelajaran Matematika Kelas VIII Semester Genap SMP Negeri 20 Kendari Tahun Pembelajaran 2016/2017 berbentuk pilihan ganda dengan jumlah soal 24 butir soal dan essay 5 butir soal. Dalam penelitian ini dianalisis butir-butir soal Tes Sumatif Mata Pelajaran Matematika Kelas VIII Semester Genap SMP Negeri 20 Kendari Tahun Pembelajaran 2016/2017 yaitu; analisis tingkat kesukaran, analisis daya pembeda, analisis validitas, analisis distractor, analisis reliabilitas, dan analisis kesalahan baku pengukuran.

\section{Tingkat Kesukaran \\ a. Pilihan Ganda}

Berdasarkan hasil analisis dengan menggunakan program iteman diperoleh data sebagai berikut:

\section{Tabel 1}

Analisis Tingkat Kesukaran Butir Soal Tes Sumatif Mata Pelajaran Matematika Kelas VIII Semester Genap SMP Negeri 20 Kendari Tahun Pembelajaran 2016/2017

\begin{tabular}{|c|c|c|c|}
\hline Kategori Soal & Nomor Butir Soal & Jumlah & Persentase (\%) \\
\hline Sukar & $4,11,15$, dan 19 & 4 & 17,39 \\
\hline Sedang & $1,2,3,5,6,7,8,9,10,12,13,14,16,17,18$, & 18 & 78,26 \\
\hline Mudah & 20,21, dan 22 & 1 & 4,35 \\
\hline \multicolumn{2}{|c|}{23} & 23 & 100 \\
\hline
\end{tabular}

Berdasarkan tabel diatas menunjukkan bahwa ada 1 butir soal $(4,35 \%)$ berkategori mudah, 18 butir soal $(78,26 \%)$ berkategori sedang, dan 4 butir soal $(17,39 \%)$ berkategori sukar. Dengan demikian, 18 butir soal $(78,26 \%)$ berkriteria baik yakni butir soal nomor 1, 2, 3, 5, $6,7,8,9,10,12,13,14,16,17,18,20,21$, dan 22 dan 5 butir soal $(21,74 \%)$ berkriteria tidak baik yakni butir soal 4, 11, 15, 19, dan 23 .

b. Essay

Berdasarkan hasil analisis dengan menggunakan rumus $T K=\frac{S_{A}+S_{B}}{n \text { maks }}$, diperoleh data sebagai berikut: 
Tabel 2

Analisis Tingkat Kesukaran Butir Soal Tes Sumatif Mata Pelajaran Matematika Kelas VIII Semester Genap SMP Negeri 20 Kendari Tahun Pembelajaran 2016/2017

\begin{tabular}{|c|c|c|c|c|c|c|c|}
\hline No. Soal & $\mathrm{N}$ & $\operatorname{Max}$ & $S_{A}$ & $S_{B}$ & $S_{A}+S_{B}$ & Indeks Kesukaran & Kategori Soal \\
\hline 1 & 88 & 25 & 449 & 66 & 515 & 0,234 & Sukar \\
\hline 2 & 88 & 9 & 192 & 65 & 257 & 0,324 & Sedang \\
\hline 3 & 88 & 19 & 202 & 52 & 254 & 0,151 & Sukar \\
\hline 4 & 88 & 10 & 85 & 30 & 115 & 0,131 & Sukar \\
\hline 5 & 88 & 13 & 210 & 60 & 270 & 0,236 & Sukar \\
\hline
\end{tabular}

Berdasarkan tabel 2, secara ringkas dapat dibuat persentase analisis tingkat kesukaran butir soal yang disajikan pada Tabel 3 berikut.

Tabel 3

Persentase Analisis Tingkat Kesukaran Butir Soal Tes Sumatif Mata Pelajaran Matematika Kelas VIII Semester Genap SMP Negeri 20 Kendari Tahun Pembelajaran 2016/2017

\begin{tabular}{|c|c|c|c|}
\hline Kategori Soal & Nomor Butir Soal & Jumlah & Persentase (\%) \\
\hline Sukar & $1,3,4$, dan 5 & 4 & 80 \\
\hline Sedang & 2 & 1 & 20 \\
\hline Mudah & - & - & \\
\hline \multicolumn{2}{|c|}{ Jumlah } & 5 & 100 \\
\hline
\end{tabular}

Berdasarkan tabel diatas menunjukan bahwa ada 0 butir soal $(0 \%)$ berkategori mudah, 1 butir soal $(20 \%)$ berkategori sedang, dan 4 butir soal $(80 \%)$ berkategori sukar. Dengan demikian, terdapat 1 butir soal $(20 \%)$ berkriteria baik yakni butir soal nomot 2 dan 4 butir soal $(80 \%)$

Tabel 4

berkriteria tidak baik yakni butir soal nomor 1, 3, 4, dan 5 .

2. Daya Pembeda

a. Pilihan Ganda

Berdasarkan hasil analisis dengan menggunakan program iteman, maka dapat diperoleh data sebagai berikut:

Analisis Daya Pembeda Butir Soal Tes Sumatif Mata Pelajaran Matematika Kelas VIII Semester Genap SMP Negeri 20 Kendari Tahun Pembelajaran 2016/2017

\begin{tabular}{|c|c|c|c|}
\hline Kategori Soal & Nomor Butir Soal & $\max$ & Persentase (\%) \\
\hline Bertanda Negatif & 4 & 1 & 4,35 \\
\hline Jelek & 19 & 1 & 4,35 \\
\hline Cukup & $2,5,6,7,15,17,18,21,22$, dan 23 & 10 & 43,48 \\
\hline Baik & $1,3,8,9,11,12,13,14,16$, dan 20 & 10 & 43,48 \\
\hline Baik Sekali & 10 & 1 & 4,35 \\
\hline \multicolumn{2}{|c|}{ Jumlah } & 23 & 100 \\
\hline
\end{tabular}

Berdasarkan tabel diatas menunjukkan bahwa ada 1 butir soal $(4,35 \%)$ mempunyai daya pembeda jelek sekali karena bernilai negatif yakni butir soal nomor 4,1 butir soal $(4,35 \%)$ mempunyai daya pembeda jelek yakni butir soal nomor 19,10 butir soal $(43,48 \%)$ berkategori cukup yakni butir soal nomor $2,5,6,7,15,17$,

$18,21,22$, dan 23,10 butir soal $(43,48 \%)$ mempunyai daya pembeda baik yakni butir soal nomor $1,3,8,9,11,12,13,14,16$, dan 20 , dan 1 butir soal $(4,35 \%)$ mempunyai daya pembeda baik sekali yakni butir soal nomor 10. Dengan demikian, terdapat 11 butir soal $(47,83 \%)$ dengan daya pembeda baik yakni butir soal nomor $1,3,8$, $9,10,11,12,13,14,16$, dan 20 dan 12 butir soal 
$(52,17 \%)$ berkategori tidak baik yakni butir soal nomor 2, 4, 5, 6, 7, 15, 17, 18, 19, 21, 22, dan 23 . b. Essay
Berdasarkan hasil analisis dengan menggunakan rumus $D P=\frac{S_{A}-S_{B}}{1 / 2 n \cdot m a k s}$, diperoleh data sebagai berikut:

\section{Tabel 5}

Analisis Daya Pembeda Butir Soal Tes Sumatif Mata Pelajaran Matematika Kelas VIII Semester Genap SMP Negeri 20 Kendari Tahun Pembelajaran 2016/2017

\begin{tabular}{|c|c|c|c|c|c|c|c|}
\hline No. Soal & $\mathrm{N}$ & Max & $S_{A}$ & $S_{B}$ & $S_{A}-S_{B}$ & Daya Pembeda & Kategori Soal \\
\hline 1 & 88 & 25 & 449 & 66 & 383 & 0,348 & Cukup \\
\hline 2 & 88 & 9 & 192 & 65 & 127 & 0,321 & Cukup \\
\hline 3 & 88 & 19 & 202 & 52 & 150 & 0,179 & Jelek \\
\hline 4 & 88 & 10 & 85 & 30 & 55 & 0,125 & Jelek \\
\hline 5 & 88 & 13 & 210 & 60 & 150 & 0,262 & Cukup \\
\hline
\end{tabular}

Berdasarkan Tabel 5, secara ringkas dapat pembeda butir soal yang disajikan pada Tabel 6 berikut.

dibuat persentase secara keseluruhan analisis daya

Tabel 6

Persentase Analisis Daya Pembeda Butir Soal Tes Sumatif Mata Pelajaran Matematika Kelas VIII Semester Genap SMP Negeri 20 Kendari Tahun Pembelajaran 2016/2017

\begin{tabular}{|c|c|c|c|}
\hline Kategori Soal & Nomor Butir Soal & $\operatorname{Max}$ & Persentase (\%) \\
\hline Bertanda Negatif & - & - & - \\
\hline Jelek & 3 dan 4 & 2 & 40 \\
\hline Cukup & 1,2, dan 5 & 3 & 60 \\
\hline Baik & - & - & - \\
\hline Baik Sekali & - & - & - \\
\hline \multicolumn{2}{|c|}{ Jumlah } & 5 & 100 \\
\hline
\end{tabular}

Berdasarkan tabel diatas menunjukkan bahwa ada 0 butir soal $(0 \%)$ berkategori jelek sekali, 2 butir soal (40\%) berkategori jelek, 3 butir soal $(60 \%)$ berkategori cukup, 0 butir soal $(0 \%)$ berkategori baik, dan 0 butir soal $(0 \%)$ berkategori baik sekali. Dengan demikian, semua butir soal tersebut tidak mempunyai daya pembeda baik.

3. Validitas

a. Pilihan Ganda

Berdasarkan hasil perhitungan dengan menggunakan program iteman dapat diperoleh data sebagai berikut:

Tabel 7

\section{Analisis Validitas Butir Soal Tes Sumatif Mata Pelajaran Matematika Kelas VIII Semester Genap SMP Negeri 20 Kendari Tahun Pembelajaran 2016/2017}

\begin{tabular}{|c|c|c|c|}
\hline Nomor Soal & $\mathrm{r}_{\text {hit }}$ & $\mathrm{r}_{\text {tabel }}$ & Kategori Soal \\
\hline 1 & 0,371 & 0,209 & Valid \\
\hline 2 & 0,169 & 0,209 & Invalid \\
\hline 3 & 0,461 & 0,209 & Valid \\
\hline 4 & $-0,130$ & 0,209 & Invalid \\
\hline 5 & 0,280 & 0,209 & Valid \\
\hline 6 & 0,195 & 0,209 & Invalid \\
\hline 7 & 0,198 & 0,209 & Invalid \\
\hline 8 & 0,490 & 0,209 & Valid \\
\hline 9 & 0,358 & 0,209 & Valid \\
\hline 10 & 0,566 & 0,209 & Valid \\
\hline 11 & 0,282 & 0,209 & Valid \\
\hline
\end{tabular}




\begin{tabular}{|c|c|c|c|}
\hline 12 & 0,388 & 0,209 & Valid \\
\hline 13 & 0,436 & 0,209 & Valid \\
\hline 14 & 0,349 & 0,209 & Valid \\
\hline 15 & 0,283 & 0,209 & Valid \\
\hline 16 & 0,436 & 0,209 & Valid \\
\hline 17 & 0,309 & 0,209 & Valid \\
\hline 18 & 0,270 & 0,209 & Valid \\
\hline 19 & 0,153 & 0,209 & Invalid \\
\hline 20 & 0,327 & 0,209 & Valid \\
\hline 21 & 0,246 & 0,209 & Valid \\
\hline 22 & 0,283 & 0,209 & Valid \\
\hline 23 & 0,272 & 0,209 & Valid \\
\hline
\end{tabular}

Berdasarkan tabel 7, secara ringkas dapat dibuat persentase analisis validitas butir soal yang disajikan pada Tabel 8 berikut.

Tabel 8

Persentase Analisis Validitas Butir Soal Tes Sumatif Mata Pelajaran Matematika Kelas VIII Semester Genap SMP Negeri 20 Kendari Tahun Pembelajaran 2016/2017

\begin{tabular}{|c|c|c|c|}
\hline Kategori Soal & Nomor Butir Soal & Jumlah Soal & Persentase (\%) \\
\hline Valid & $\begin{array}{c}1,3,5,8,9,10,11,12,13,14,15, \\
16,17,18,20,21,22, \text { dan } 23\end{array}$ & 18 & 78,26 \\
\hline Invalid & $2,4,6,7$, dan 19 & 5 & 21,74 \\
\hline & Jumlah & 23 & 100 \\
\hline
\end{tabular}

Berdasarkan tabel diatas menunjukkan bahwa ada 5 butir soal $(21,74 \%)$ yang dikatakan invalid yaitu butir soal nomor 2, 4, 6, 7, dan 19, dan terdapat 18 butir soal $(78,26 \%)$ dikatakan valid yaitu butir soal nomor $1,3,5,8,9,10,11$, $12,13,14,15,16,17,18,20,21,22$, dan 23.

b. Essay dengan angka kasar atau $r_{X Y}=\frac{N \sum X Y-\left(\sum X\right)\left(\sum Y\right)}{\sqrt{\left\{N \sum X^{2}-\left(\sum X\right)^{2}\right\}\left\{N \sum Y^{2}-\left(\sum Y\right)^{2}\right\}}}$ , diperoleh data sebagai berikut:

Tabel 9

Analisis Validitas Butir Soal Tes Sumatif Mata Pelajaran Matematika Kelas VIII Semester Genap SMP Negeri 20 Kendari Tahun Pembelajaran 2016/2017

\begin{tabular}{|c|c|c|c|c|c|c|c|c|c|}
\hline No. Soal & $\mathrm{N}$ & $\sum X$ & $\sum Y$ & $\sum X Y$ & $\sum X^{2}$ & $\sum Y^{2}$ & $\mathrm{r}_{\text {hit }}$ & $\mathrm{r}_{\text {tabel }}$ & Keterangan \\
\hline 1 & 88 & 515 & 1409 & 16215 & 8327 & 37203 & 0,903 & 0,209 & Valid \\
\hline 2 & 88 & 257 & 1409 & 6772 & 1098 & 37203 & 1,178 & 0,209 & Valid \\
\hline 3 & 88 & 254 & 1409 & 6080 & 1432 & 37203 & 0,629 & 0,209 & Valid \\
\hline 4 & 88 & 115 & 1409 & 2533 & 269 & 37203 & 0,525 & 0,209 & Valid \\
\hline 5 & 88 & 270 & 1409 & 6438 & 1434 & 37203 & 0,710 & 0,209 & Valid \\
\hline
\end{tabular}

Berdasarkan tabel 9, secara ringkas dapat dibuat persentase analisis Validitas butir soal yang disajikan pada Tabel 10 berikut. 
Tabel 10

Hasil Analisis Validitas Butir Soal Tes Sumatif Mata Pelajaran Matematika Kelas VIII Semester Genap SMP Negeri 20 Kendari Tahun Pembelajaran 2016/2017

\begin{tabular}{|c|c|c|c|}
\hline Kategori Soal & Nomor Butir Soal & Jumlah Soal & Persentase (\%) \\
\hline Valid & $1,2,3,4$ dan 5 & 5 & 100 \\
\hline Invalid & - & - & - \\
\hline \multicolumn{2}{|c|}{ Jumlah } & 5 & 100 \\
\hline
\end{tabular}

Berdasarkan tabel diatas menunjukkan bahwa dari 5 butir soal dapat dikatakan sebagai tes yang valid, karena sebanyak 5 butir soal semua butir soal $(100 \%)$ dapat dikatakan sebagai tes yang valid.

\section{Distractor (Pengecoh)}

Berdasarkan hasil analisis dengan menggunakan program Iteman yang ditunjukkan oleh Prop. Endorsing pada Alternative Statistics dapat dilihat pada tabel berikut:

Tabel 11

Persentase Analisis Pengecoh Butir Soal Tes Sumatif Mata Pelajaran Matematika Kelas VIII Semester Genap SMP Negeri 20 Kendari Tahun Pembelajaran 2016/2017

\begin{tabular}{|c|c|c|c|}
\hline Kategori & Nomor Butir Soal & Jumlah & Persentase (\%) \\
\hline \multirow{2}{*}{ Berfungsi } & $\begin{array}{l}1,2,3,4,5,6,7,8,9,10,11,12, \\
13,14,15,16,17,18,19, \text { dan } 21\end{array}$ & 21 & 91,30 \\
\hline Tidak Berfungsi & 22 dan 23 & 2 & 8,70 \\
\hline \multicolumn{2}{|l|}{ Jumlah } & 23 & 100 \\
\hline
\end{tabular}

Berdasarkan tabel diatas menunjukkan bahwa dari 23 butir soal terdapat 21 butir soal $(91,30 \%)$ yang pengecohnya sudah berfungsi dan terdapat 2 butir soal $(8,70 \%)$ yang pengecohnya tidak berfungsi.

\section{Reliabilitas}

a. Pilihan Ganda

Berdasarkan hasil analisis dengan menggunakan program Iteman yang ditunjukkan oleh alpha pada skala statistik (scale statistics). Besarnya nilai reliabilitas pada tes sumatif mata pelajaran matematika kelas VIII semester genap SMP Negeri 20 Kendari tahun pembelajaran 2016/2017 diperoleh nilai sebesar 0.580. Hal ini menunjukkan bahwa tes hasil belajar dari 23 butir soal yang diikuti oleh 88 peserta tes tersebut memiliki reliabilitas tes yang berkategori sedang.

b. Essay

Berdasarkan hasil analisis dengan menggunakan rumus $r_{11}=\left(\frac{n}{n-1}\right)\left(1-\frac{\sum S_{i}{ }^{2}}{S_{t}{ }^{2}}\right)$, diperoleh data sebagai berikut:

Tabel 12

Analisis Reliabilitas Tes Sumatif Mata Pelajaran Matematika Kelas VIII Semester Genap SMP Negeri 20 Kendari Tahun Pembelajaran 2016/2017

\begin{tabular}{|c|c|c|c|c|c|c|}
\hline $\mathrm{N}$ & $\mathrm{N}$ & $\mathrm{n}-1$ & $\sum S_{i}{ }^{2}$ & $S_{t}{ }^{2}$ & $r_{11}=\left(\frac{n}{n-1}\right)\left(1-\frac{\sum S_{i}{ }^{2}}{S_{t}{ }^{2}}\right)$ & Keterangan \\
\hline 88 & 5 & 4 & 80,5 & 166,398 & 0,645 & Sedang \\
\hline
\end{tabular}

Berdasarkan tabel diatas, besarnya nilai reliabilitas pada tes sumatif mata pelajaran matematika kelas VIII semester genap SMP Negeri 20 Kendari tahun pembelajaran 2016/2017 diperoleh nilai sebesar 0.645. Hal ini menunjukkan bahwa tes hasil belajar dengan 5 butir soal yang diikuti oleh 88 peserta tes tersebut memiliki reliabilitas tes yang berkategori sedang.

\section{Kesalahan Baku Pengukuran (KBP)}

a. Pilihan Ganda

Berdasarkan hasil analisis dengan menggunakan program Iteman, kesalahan baku pengukuran dapat diketahui dari Standar Error of Measurement (SEM) pada skala statistik (scale statistic). Besarnya nilai kesalahan baku pengukuran pada tes sumatif mata pelajaran 
matematika kelas VIII semester genap SMP Negeri 20 Kendari tahun pembelajaran 2016/2017 diperoleh nilai SEM sebesar 2,191.

\section{b. Essay}

Berdasarkan hasil analisis dengan menggunakan rumus $S m=S D \sqrt{1-r_{11}}$ diperoleh data sebagai berikut:

Tabel 13

Analisis Kesalahan Baku Pengukuran Tes Sumatif Mata Pelajaran Matematika Kelas VIII Semester Genap SMP Negeri 20 Kendari Tahun Pembelajaran 2016/2017

\begin{tabular}{|c|c|c|}
\hline SD & $r_{11}$ & $S m=S D \sqrt{1-r_{11}}$ \\
\hline 12,9 & 0,645 & 7,686 \\
\hline
\end{tabular}

Berdasarkan tabel diatas dari 5 butir soal tes sumatif mata pelajaran matematika kelas VIII semester genap SMP Negeri 20 Kendari tahun pembelajaran 2016/2017 menunjukan bahwa simpangan baku atau standar deviasi skor tes sebesar 12,9 dan koefisien reliabilitasnya 0,645 maka diperoleh nilai sebesar 7,686.

\section{Pembahasan}

Berdasarkan hasil analisis ditemukan pada soal pilihan ganda dari 23 butir soal terdapat 1 butir soal $(4,35 \%)$ berkategori mudah, 18 butir soal $(78,26 \%)$ berkategori sedang, dan 4 butir soal $(17,39 \%)$ berkategori sukar. Jadi, pada penelitian ini perbandingan proporsi tingkat kesukaran adalah $1: 18: 4$ (4,35\% mudah : 78,26\% sedang : $17,39 \%$ sukar). Hal ini menunjukkan bahwa tingkat kesukaran soal pilihan ganda belum memenuhi kriteria soal yang dipersyaratkan sesuai dengan acuan yang ada yakni $7: 11: 5(30 \%$ mudah : 50\% sedang : 20\% sukar). Sedangkan untuk soal essay ditemukan dari 5 butir soal terdapat 0 butir soal (0\%) berkategori mudah, 1 butir soal $(20 \%)$ berkategori sedang, dan 4 butir soal $(80 \%)$ berkategori sukar. Jadi, pada penelitian ini perbandingan proporsi tingkat kesukaran adalah $0: 1: 4$ (0\% mudah: $20 \%$ sedang: $80 \%$ sukar). Hal ini menunjukkan bahwa tingkat kesukaran soal essay belum memenuhi kriteria soal yang dipersyaratkan sesuai dengan acuan yang ada yakni yakni 1:3:1 (30\% mudah : 50\% sedang : $20 \%$ sukar). Dengan demikian, secara keseluruhan baik soal pilihan ganda dan soal essay dapat disimpulkan bahwa tingkat kesukaran butir soal tes sumatif mata pelajaran matematika kelas VIII semester genap SMP Negeri 20 Kendari tahun pembelajaran 2016/2017 belum termasuk baik.
Berdasarkan hasil analisis pada soal pilihan ganda dari 23 butir soal terdapat 1 butir soal $(4,35 \%)$ mempunyai daya pembeda jelek sekali karena bernilai negatif, 1 butir soal $(4,35 \%)$ mempunyai daya pembeda jelek, 10 butir soal $(43,48 \%)$ mempunyai daya pembeda cukup, 10 butir soal $(43,48 \%)$ mempunyai daya pembeda baik, dan 1 butir soal $(4,35 \%)$ mempunyai daya pembeda baik sekali. Dengan demikian, dapat dikatakan sebanyak 11 butir soal $(47,83 \%)$ mempunyai daya pembeda baik dan 12 butir soal $(52,17 \%)$ mempunyai daya pembeda tidak baik. Hal ini menunjukkan bahwa daya pembeda soal pilihan ganda dinyatakan tidak baik berdasarkan analisis daya pembeda. Sedangkan untuk soal essay dari 5 butir soal terdapat 0 butir soal $(0 \%)$ mempunyai daya pembeda jelek sekali, 2 butir soal (40\%) mempunyai daya pembeda jelek, 3 butir soal (60\%) mempunyai daya pembeda cukup, 0 butir soal (0\%) mempunyai daya pembeda baik, dan 0 butir soal (0\%) mempunyai daya pembeda baik sekali. Dengan demikian, semua butir soal tersebut tidak mempunyai daya pembeda baik. Hal ini menunjukkan bahwa daya pembeda soal essay dinyatakan tidak baik berdasarkan analisis daya pembeda. Dengan demikian, secara keseluruhan baik soal pilihan ganda dan soal essay dapat disimpulkan bahwa daya pembeda butir soal tes sumatif mata pelajaran matematika kelas VIII semester genap SMP Negeri 20 Kendari tahun pembelajaran 2016/2017 belum mempunyai daya pembeda baik.

Berdasarkan hasil analisis soal pilihan ganda dari 23 butir soal terdapat 5 butir soal $(21,74 \%)$ berkategori tidak valid (invalid) dan terdapat 18 butir soal $(78,26 \%)$ berkategori valid. Hal ini menunjukkan bahwa tes sumatif mata pelajaran matematika kelas VIII semester genap SMP Negeri 20 Kendari tahun pembelajaran 2016/2017 dapat dikategorikan soal yang baik 
sehingga dapat mengukur kemampuan siswa dalam mengerjakan soal dan butir soal tersebut bisa digunakan untuk keperluan tes selanjutnya. Butir soal yang mempunyai korelasi sangat rendah sebaiknya dibuang saja karena tidak dapat mengukur kemampuan siswa. Sedangkan soal essay ditemukan semua butir soal $(100 \%)$ dapat dikatakan sebagai tes yang valid. Hal ini menunjukkan bahwa tes sumatif mata pelajaran matematika kelas VIII semester genap SMP Negeri 20 Kendari tahun pembelajaran 2016/2017 dapat dikategorikan soal yang sangat baik, sehingga dapat mengukur kemampuan siswa dalam mengerjakan soal dan butir soal tersebut bisa digunakan untuk keperluan tes selanjutnya. Dengan demikian, secara keseluruhan butir soal pilihan ganda dan soal essay dapat disimpulkan bahwa validitas butir soal tes sumatif mata pelajaran matematika kelas VIII semester genap SMP Negeri 20 Kendari tahun pembelajaran 2016/2017 sudah mempunyai validitas yang baik.

Berdasarkan hasil analisis dari 23 butir soal terdapat 21 butir soal $(91,30 \%)$ yang pengecohnya berfungsi dan 2 butir soal $(8,70 \%)$ yang pengecohnya tidak berfungsi. Pada butir soal nomor 22 dan 23 distractor $\mathrm{D}$ tidak berfungsi karena jumlah pemilihnya kurang dari 5\% atau lebih banyak memilih kunci jawaban. Salah satu penyebabnya pada butir soal nomor 22 kalau seandainya diganti pilihan jawabannya (option) itu kemungkinan akan berfungsi karena option D itu sangat kecil terjadi dan butir soal nomor 23 ada kemungkinan penempatan urutan option tidak mengikuti aturan penempatan pemilihan yang seharusnya karena ada dua kemungkinan, diurutkan dari yang besar ke kecil atau dari yang kecil ke besar. Pada umumnya, dapat dikatakan bahwa butir soal tes sumatif mata pelajaran matematika kelas VIII semester genap SMP Negeri 20 Kendari tahun pembelajaran 2016/2017 pengecohnya sudah berfungsi.

Berdasarkan hasil analisis soal pilihan ganda diperoleh nilai sebesar 0,580. Hal ini menunjukkan bahwa tes sumatif mata pelajaran matematika kelas VIII semester genap SMP Negeri 20 Kendari tahun pembelajaran 2016/2017 sudah mempunyai reliabilitas baik. Sedangkan untuk soal essay diperoleh nilai sebesar 0,645. Hal ini menunjukkan bahwa reliabilitas tes sumatif mata pelajaran matematika kelas VIII semester genap SMP Negeri 20 Kendari tahun pembelajaran 2016/2017 sudah mempunyai reliabilitas baik. Dengan demikian, secara keseluruhan baik soal pilihan ganda dan soal essay dapat disimpulkan bahwa reliabilitas tes sumatif mata pelajaran matematika kelas VIII semester genap SMP Negeri 20 Kendari tahun pembelajaran 2016/2017 sudah mempunyai reliabilitas baik.

Berdasarkan hasil analisis soal pilihan ganda, besarnya nilai kesalahan baku pengukuran tes sumatif mata pelajaran matematika kelas VIII semester genap SMP Negeri 20 Kendari tahun pembelajaran 2016/2017 diperoleh nilai sebesar 2,191 . Sedangkan untuk soal essay besarnya nilai kesalahan baku pengukuran pada tes sumatif mata pelajaran matematika kelas VIII semester genap SMP Negeri 20 Kendari tahun pembelajaran 2016/2017 diperoleh nilai sebesar 7,686.

Berdasarkan indikator dilihat dari segi; tingkat kesukaran (TK), daya pembeda (DB), distractor, validitas, dan reliabilatas untuk secara keseluruhan kualitas tes sumatif mata pelajaran matematika kelas VIII semester genap SMP Negeri 20 Kendari tahun pembelajaran 2016/2017 belum termasuk tes yang berkualitas baik. Tetapi, jika dilihat secara terpisah untuk tingkat kesukaran butir soal tes sumatif mata pelajaran matematika kelas VIII semester genap SMP Negeri 20 Kendari tahun pembelajaran 2016/2017 belum termasuk baik, daya pembeda butir soal tes sumatif mata pelajaran matematika kelas VIII semester genap SMP Negeri 20 Kendari tahun pembelajaran 2016/2017 belum mempuanyai daya pembeda baik, validitas butir soal tes sumatif mata pelajaran matematika kelas VIII semester genap SMP Negeri 20 Kendari tahun pembelajaran 2016/2017 sudah mempunyai validitas yang baik, distractor (pengecoh) butir soal tes sumatif mata pelajaran matematika kelas VIII semester genap SMP Negeri 20 Kendari tahun pembelajaran 2016/2017 pengecohnya sudah berfungsi, reliabilitas tes sumatif mata pelajaran matematika kelas VIII semester genap SMP Negeri 20 Kendari tahun pembelajaran 2016/2017 sudah mempunyai reliabilitas baik. 


\section{Simpulan dan Saran}

\section{Simpulan}

Berdasarkan hasil analisis dan pembahasan, maka dapat dikemukakan beberapa kesimpulan sebagai berikut:

1. Tingkat kesukaran soal pilihan ganda dan soal essay tes sumatif mata pelajaran matematika kelas VIII semester genap SMP Negeri 20 Kendari tahun pembelajaran 2016/2017 belum termasuk baik. Oleh karena, pilihan ganda dari 23 butir soal ditemukan hanya 1 soal mudah, 18 soal sedang, dan 4 soal sukar yang seharusnya dari 23 butir soal, 7 soal mudah, 11 soal sedang, 5 soal sukar. Sedangkan soal essay dari 5 butir soal ditemukan 0 butir soal mudah, 1 butir soal sedang, dan 4 butir soal sukar yang seharusnya dari 5 butir soal 1 soal mudah, 3 soal sedang, dan 1 soal sukar, supaya memenuhi kriteria tingkat kesukaran yang baik yakni $3: 5: 2$ (30\% mudah, 50\% sedang, 20\% sukar).

2. Daya pembeda soal pilihan ganda dan soal essay tes sumatif mata pelajaran matematika kelas VIII semester genap SMP Negeri 20 Kendari tahun pembelajaran 2016/2017 belum mempunyai daya pembeda baik. Oleh karena, dari 23 butir soal pilihan ganda hanya terdapat 10 butir soal $(43,48 \%)$ daya pembeda baik dan 12 butir soal $(52,17 \%)$ mempunyai daya pembeda tidak baik. Sedangkan soal essay dari 5 butir soal semua butir soal mempunyai daya pembeda tidak baik.

3. Validitas soal pilihan ganda dan soal essay tes sumatif mata pelajaran matematika kelas VIII semester genap SMP Negeri 20 Kendari tahun pembelajaran 2016/2017 sudah mempunyai validitas yang baik.

4. Distractor tes sumatif mata pelajaran matematika kelas VIII semester genap SMP Negeri 20 Kendari tahun pembelajaran 2016/2017 pengecohnya sudah berfungsi.

5. Besarnya indeks reliabilitas soal pilihan ganda tes sumatif mata pelajaran matematika kelas VIII semester genap SMP Negeri 20 Kendari tahun pembelajaran 2016/2017 sebesar 0,580 termasuk memiliki reliabilitas yang sedang. Sedangkan soal essay mempunyai indeks reliabilitas sebesar 0,645 termasuk memiliki reliabilitas sedang.
6. Besarnya kesalahan baku pengukuran (KBP) soal pilihan ganda tes sumatif mata pelajaran matematika kelas VIII semester genap SMP Negeri 20 Kendari tahun pembelajaran 2016/2017 sebesar 2,191. Sedangkan soal uraian mempunyai kesalahan baku pengukuran sebesar 7,686.

\section{Saran}

Berdasarkan hasil analisis butir soal dan kesimpulan diatas, maka dapat dikemukakan saran sebagai berikut:

1. Berdasarkan hasil penelitian ini disarankan dalam penulisan soal agar dapat menuliskan soal yang baik dan benar karena ditemukan tingkat kesukaran dan daya pembeda belum memenuhi kriteria soal yang berkualitas.

2. Apabila memungkinkan, sebaiknya soal-soal untuk soal semester di uji cobakan terlebih dahulu supaya diketahui informasi yang berkaitan dengan tingkat kesukran, daya pembeda, pengecoh, validitas, reliabilitas, dan kesalahan baku pengukuran.

\section{Daftar Pustaka}

Aliati \& Ibrahum, Muchtar. (2013). Kualitas Tes Ujian Nasional Matematika Siswa SMP Negeri Di Kabupaten Buton Utara Tahun Ajaran 2011/2012. Jurnal Penelitian Pendidikan Matematika, Vol. 1, No. 1, hal 1-10.

Arifin, Zainal. (2012). Evaluasi Pembelajaran Cetakan Ke-2. Jakarta: Direktur Jenderal Pendidikan Islam Kementrian Agama RI.

Arikunto, Suharsimi. (2016). Dasar-Dasar Evaluasi Pendidikan Edisi 2. Jakarta: Bumi Aksara.

Daryanto. (2001). Evaluasi Pendidikan. Jakarta: Rineka Cipta.

Erlina, A. (2012). Analisis Soal Ulangan Akhir Semester 1 Kelas X SMA Negeri Banyumas Mata Pelajaran Matematika Tahun Pelajaran 2011/2012. Semarang: Skripsi FKIP Institut Agama Islam Negeri Walisongo. 
Hendriana, Heris \& Soemarno, Utari. (2014). Penilaian Pembelajaran Matematika. Bandung: PT Refika Aditama.

Jihad, Asep \& Abdul Haris. (2012). Evaluasi Pembelajaran. Yogyakarta: Multi Presindo.

Liliasari, Cicylia T. Kereh, Paulus C. Tjiang, dan Jozua Sabandar. (2015). Validitas dan Reliabilitas Instrumen Tes Matematika Dasar yang Berkaitan dengan Pendahuluan Fisika Inti. Jurnal Inovasi Dan Pembelajaran Fisika, Vol. 2, No. 1, Hal. 36-46.
Sitti Fatimah. (2014). Kualitas Tes Sumatif Mata Pelajaran Matematika Kelas VIII Semester Genap SMP Negeri 2 Sawa Tahun Pelajaran 2012/2013. Kendari: Skripsi FKIP UHO tidak Dipublikasikan.

Sudijono, Anas. (2015). Pengantar Evaluasi Pendidikan. Jakarta: Rajawali Pers.

Sukardi. (2015). Evaluasi Pendidikan: Prinsip dan Operasional. Jakarta: Bumi Aksara.

Yusuf, Muri. (2015). Asesmen dan Evaluasi Pendidikan. Jakarta: Kencana. 